\title{
ANALYSIS OF THE SUPPORTING STRUCTURE OF COMPOSITE MATERIAL TOOL MACHINE USING THE FINITE ELEMENT METHOD
}

\author{
Bogdan Ćirković, Ivica Čamagić, Nemanja Vasić, Zijah Burzić, Boris Folić
}

Original scientific paper

Machines aimed for different purposes must be designed taking into account specific shape, type of load and materials they are made of. Nowadays different design solutions can easily be examined by using the finite element method. In this paper an example is given of examining a machine with closed supporting structure, made of iron-concrete, dynamically loaded composite material.

Keywords: composite material iron-concrete; dynamic loading; finite element method; supporting structure

\section{Analiza noseće konstrukcije alatnog stroja od kompozitnog materijala metodom konačnih elemenata}

Izvorni znanstveni članak Strojevi različite namjene moraju biti projektirani uzimajući u obzir specifičan oblik, vrstu opterećenja i materijal od kojeg su izrađeni. Različita projektna rješenja danas se mogu lako provjeriti primjenom metode konačnih elemenata. U ovom radu dan je primjer takve provjere zatvorene noseće konstrukcije alatnog stroja izrađene od kompozitnog materijala željezo-beton, dinamički opterećene.

Ključne riječi: dinamičko opterećenje; kompozitni materijal željezo-beton; metoda konačnih elemenata; noseća konstrukcija

\section{Introduction}

The theory of continuum mechanics represents the basis for application of the finite element method (FEM) to solve a wide range of problems $[1 \div 4]$, including modelling of composite materials, $[5,6]$. Here the FEM is used for analysing the dynamic behaviour of the supporting structure of tool machine, made of composite material.

Fibrous composite material iron-concrete is a new material used for supporting structures, with concrete matrix and fibre reinforcing steel $[7,8]$. Such a composite material, iron-concrete, was used for the supporting structure of a tool machine, as described in this paper, and analysed using a representative example.

\section{Modelling by the finite element method}

The supporting structure of tool machine is its fundamental part which functions are as follows:

- to connect all the other elements of the machines in a single unit and maintain their configuration;

- to sustain loads to which the machine is exposed during operation.

The model of the carrying structure analysed in this paper is a $2 \mathrm{D}$, since but the distribution of all physical quantities does not change in one direction. Therefore the plane stress model with isoparametric two-dimensional finite elements is applied. Examining the local influences (openings and holes) and the stress concentration is not part of this study, but can be easily obtained through the use of the finite element method, as shown in $[9 \div 13]$.

The model of the supporting structure was made, Figure 1, in accordance with the previous analyses [14] Toward this aim, the supports are located as shown in Fig. 1, marked by "123", "12" and "2". The mark "123" indicates no movement in $X, Y$ and $Z$ directions, the mark "12" no movement in $X, Y$ direction, and the mark "2" no movement in the direction of the $Y$ axis.

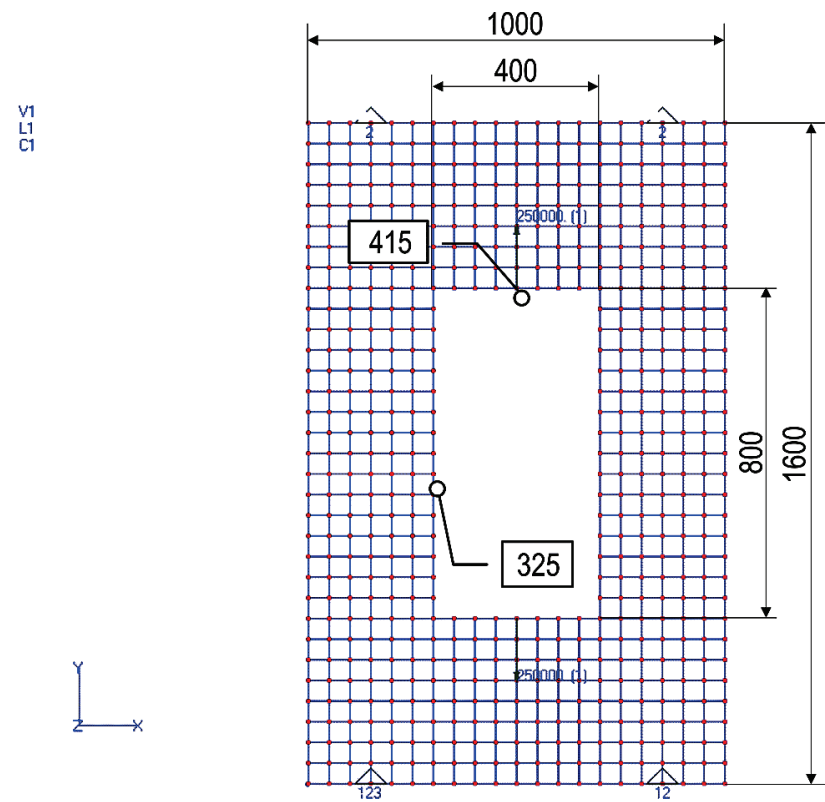

Figure 1 Supporting structure model by the finite element method

Such distribution of supports reduces displacements and strains of the pillars to the minimum. This reduction is of the utmost importance, since the composite material iron-concrete has poor tensile characteristics.

The traverse (red) and pillars (blue) displacements are shown in the critical points, Fig. 2, vs. time, given in msec. Total observed time during traverse and pillars movement was $1 \mathrm{~s}$.

The critical points are in the middle of the traverse (415) and in the middle of the pillar (325), as shown in Figs. 1 and 2, where the numbers in parentheses represent the number of nodes in the finite element mesh, in which the values were measured.

Figs. 3 and 4 show in the same way the traverse and pillars displacements for two different inputs, circular frequency (Fig. 3) and modulus of elasticity (Fig. 4). 


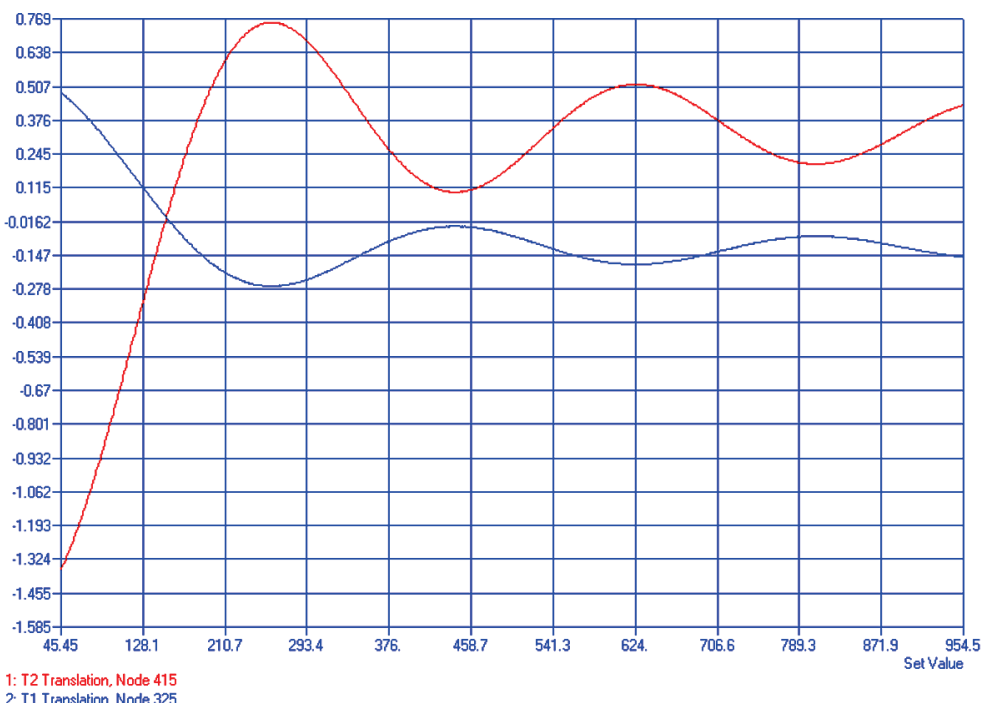

Figure 2 The traverse and pillar displacement

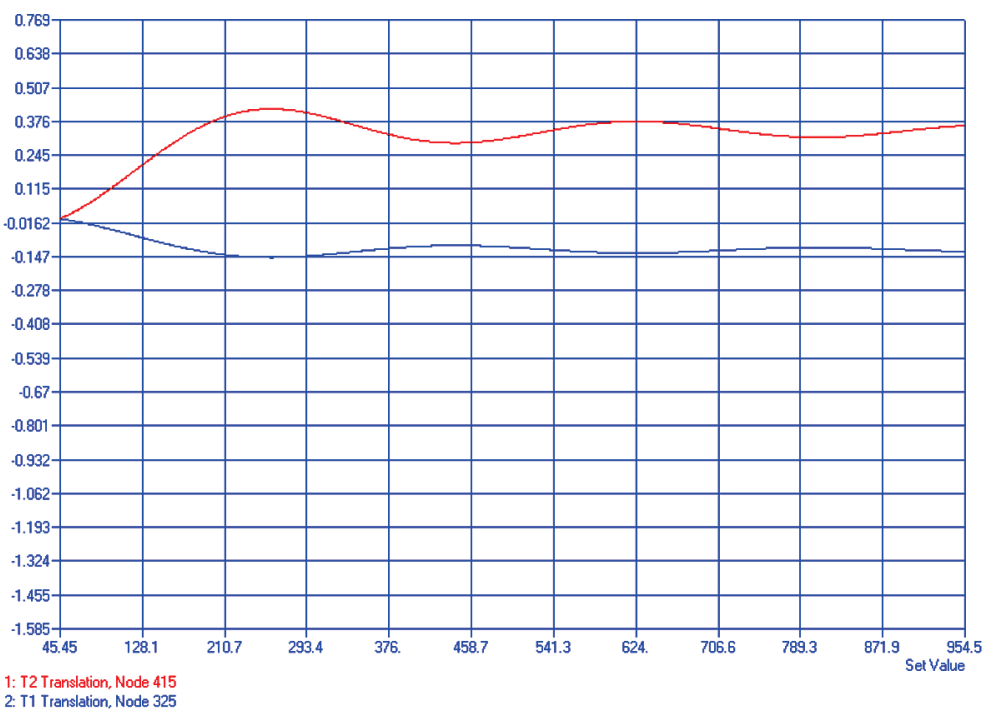

Figure 3 The traverse and pillar displacement - effect of circular frequency

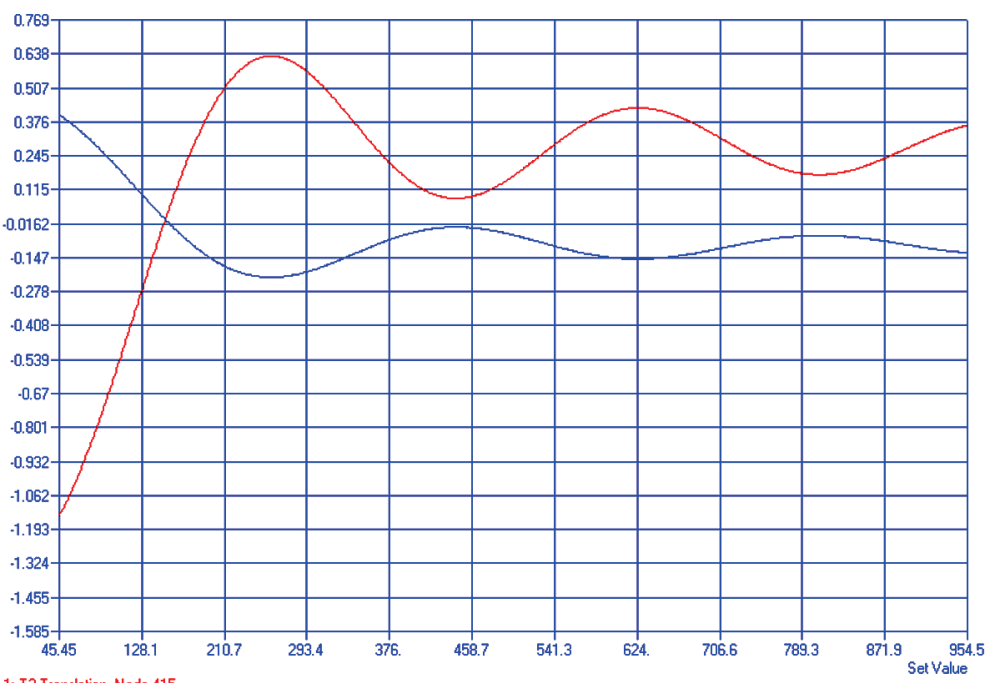

1: $T 2$ Translation, Node 415
2: 11 Translation, Node 325

Figure 4 The traverse and pillar displacement - effect of modulus of elasticity

Fig. 5 shows displacements of all points in the carrying structure in a certain moment during the working time of the machine, which was earlier identified as the most critical one, i.e. the moment when the amplitudes are maximal, as shown in Fig. 2.
In order to investigate the influence of material on the dynamic behaviour of supporting structure, elastic modulus of the composite material has been changed in accordance with previous research $[9 \div 12,15]$, as given in Tab. 1. 
$\mathrm{V} 1$
$\mathrm{L1}$
$\mathrm{C1}$
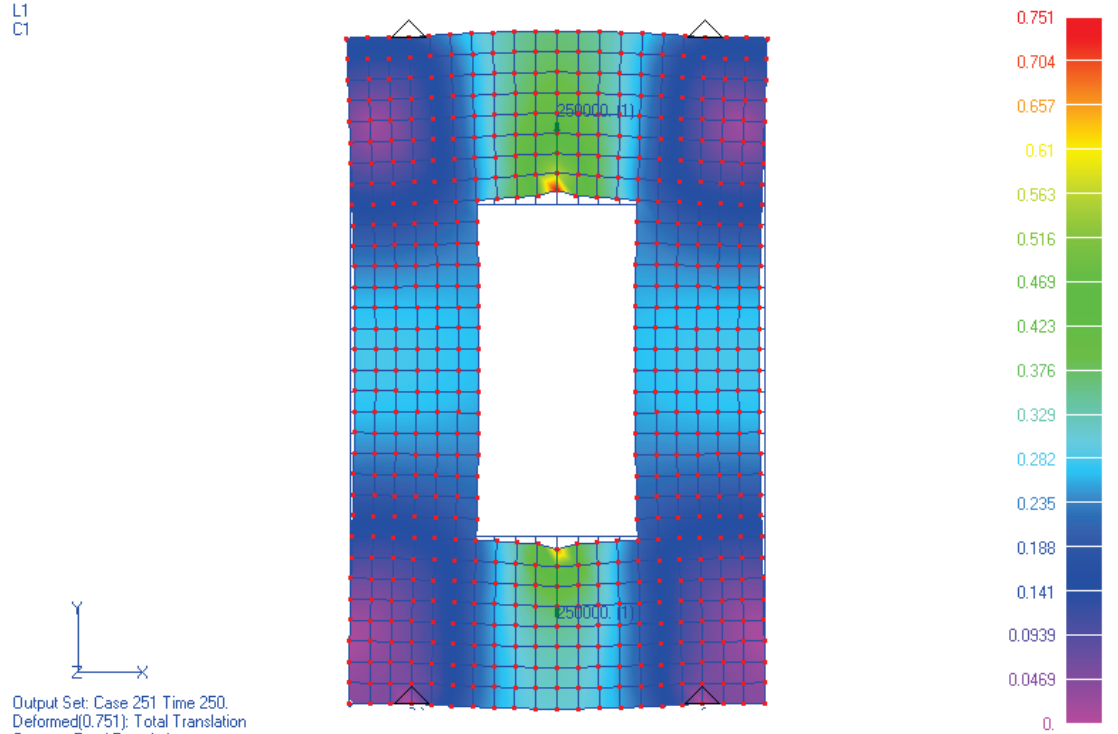

Figure 5 Displacements of the supporting structure at the critical time $250 \mathrm{~ms}$
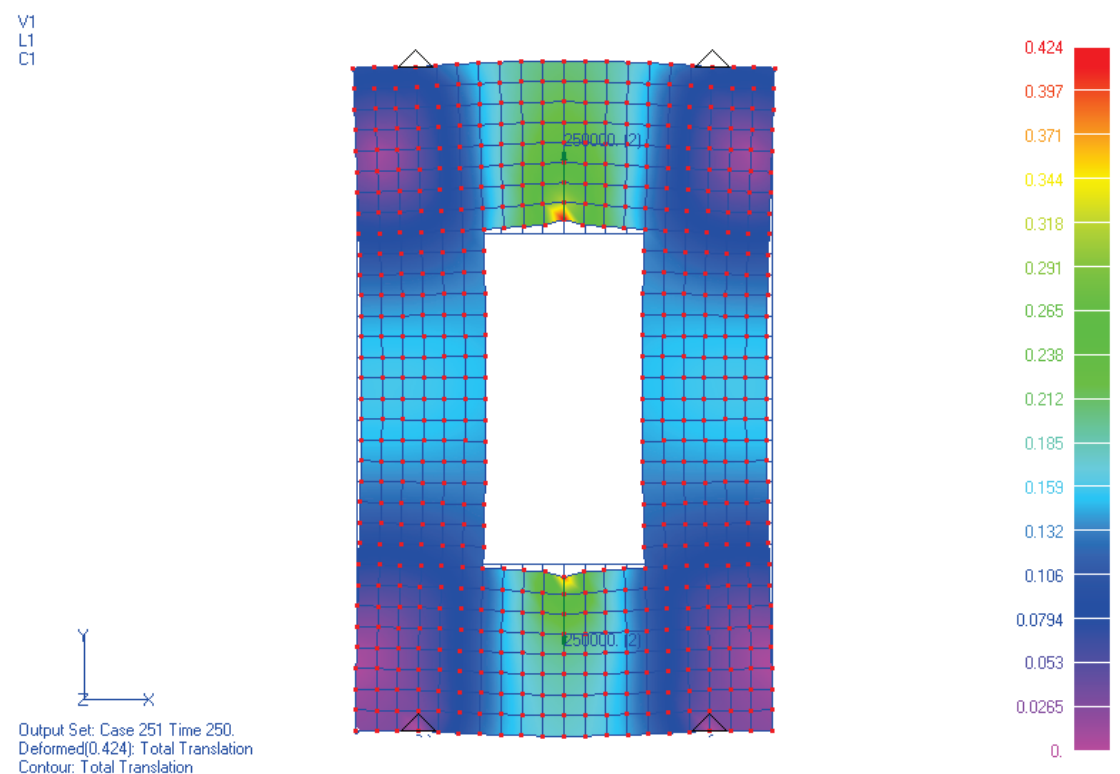

Figure 6 Displacements of the supporting structure at the critical time $250 \mathrm{~ms}$ - effect of circular frequency
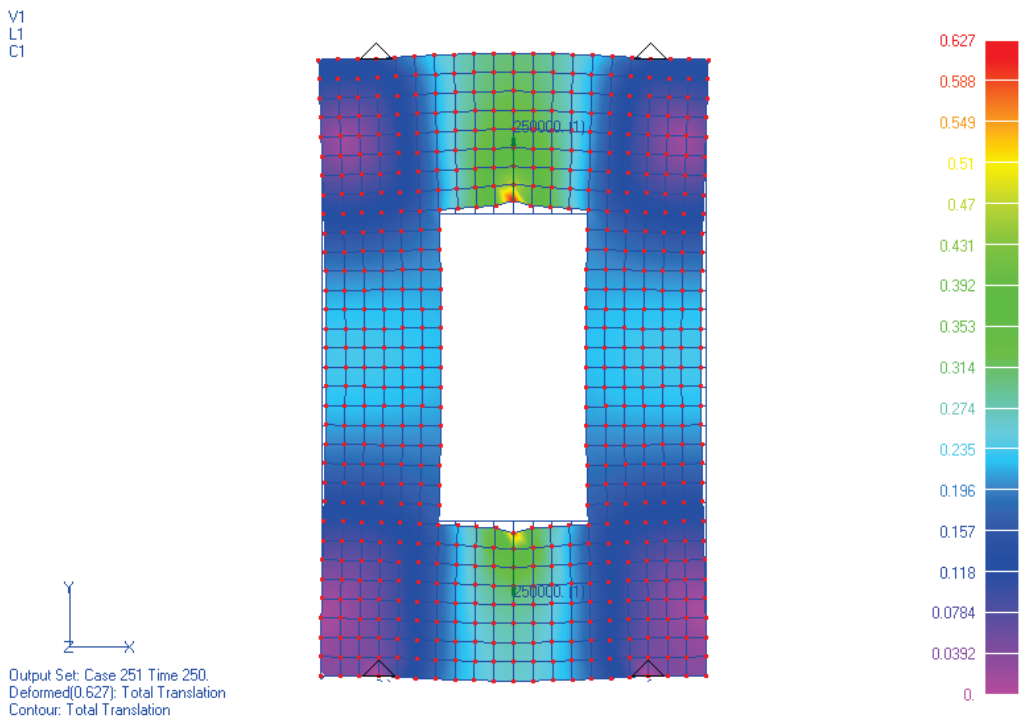

Figure 7 Displacements of the supporting structure at the critical time $250 \mathrm{~ms}$ - effect of modulus of elasticity 
Another important influence is due to workload, as defined by the formula, [16]:

$$
F(t)=\frac{F_{n}}{t_{\mathrm{ob}}} \cdot t=\frac{F_{n}}{t_{\mathrm{ob}}}\left[\pi-2 \sum_{n=1}^{\infty} \frac{\sin (n \cdot \Omega \cdot t)}{n}\right] .
$$

The required data remained the same as in the first model, as well as other values that affect the dynamic behaviour, whereas the difference appears only in the size of forced oscillations of the workload.

In Figs. 6 and 7 the effects of circular frequency of coercive force and elastic modulus are shown, respectively, while the other parameters related to the design and characteristics of the composite material were the same. Results in Figs. 6 and 7 indicate that the reduction of circular frequency of coercive force and the increase of modulus of elasticity improve characteristics of the composite material and thus reduce the dynamic shifts and better dynamic behaviour of the entire supporting structure.

Table 1

\begin{tabular}{|l|c|c|c|c|c|}
\hline \multicolumn{1}{|c|}{ Size } & Label & Unit & $\begin{array}{c}\text { Diagram } \\
2\end{array}$ & $\begin{array}{c}\text { Diagram } \\
4\end{array}$ & $\begin{array}{c}\text { Diagram } \\
6\end{array}$ \\
\hline $\begin{array}{l}\text { The modulus } \\
\text { of elasticity of } \\
\text { composite } \\
\text { material }\end{array}$ & $E$ & $\mathrm{MPa}$ & \multicolumn{2}{|c|}{44559} & 55000 \\
\hline $\begin{array}{l}\text { Circular } \\
\text { frequency } \\
\text { of coercive } \\
\text { force }\end{array}$ & $\Omega$ & $\mathrm{s}^{-1}$ & 50 & 10 & 50 \\
\hline
\end{tabular}

\section{Conclusion}

Based on the solutions provided by the finite element method, one can examine different designs of the supporting structure of tool machine.

Results presented in this paper have proved that the reduction of circular frequency of coercive force and the increase of modulus of elasticity have positive effect on dynamic behaviour of supporting structure made of composite material. These effects have also been quantified in terms of reduced displacements.

\section{References}

[1] Deng, W. J.; Li, Q.; Xie, Z. C.; Lin, P. Numerical Analysis of Rectangular Groove Cutting with Different RC Tools. // International Journal of Simulation Modelling. 12, 2(2013), pp. $120-131$.

[2] Vijay Sekar, K. S.; Pradeep Kumar M. Optimising Flow Stress Input for Machining Simulations Using Taguchi Methodology. // International Journal of Simulation Modelling. 11, 1(2012), pp. 17-28.

[3] Volk, M.; Nardin, B.; Dolsak, B. Determining the optimal area-dependent blank holder forces in deep drawing using the response surface method. // Advances in Production Engineering \& Management. 9, 2(2014), pp. 71-82.

[4] Dezelak, M.; Stepisnik, A.; Pahole, I.; Ficko, M. Evaluation of Twist Springback Prediction after an AHSS Forming Process. // International Journal of Simulation Modelling. 13, 2(2014), pp. 171-182.
[5] Maneski, T.; Milošević-Mitic, V. Numerical and experimental diagnostics of structural strength. // Structural Integrity and Life. 10, 1(2010), pp. 3-10.

[6] Tomić, R. Experimental Verification of In-Plane Stress Calculation of Thin Composite Plate Based on the Finite Element Method. // Structural Integrity and Life. 12, 1(2012), pp. 71-77.

[7] Bogatinoski, Z.; Arsova-Milosevska, G.; Trajanoska, B. Numerical Modelling of Beam-Column Connections at Multi-Storey Composite Structures. // Structural Integrity and Life. 10, 3(2010), pp. 245-248.

[8] Barile, C.; Casavola, C.; Pappalettere, C.; Tursi, F. RFI Composite Materials Behaviour. // Structural Integrity and Life. 10, 3(2010), pp. 209-213.

[9] Nikolić, V.; Dolićanin, Ć.; Radojković, M. Application of finite element analysis of thin steel plate with holes. Tehnički vjesnik-Technical Gazette. 18, 1(2011), p. 57-62.

[10] Milošević-Mitić, V.; Gaćeša, B.; Anđelić, N.; Maneski, T. Numerical Calculation of the Water-Tube Boiler Using Finite Element of the Orthotropic Plate. // Structural Integrity and Life. 12, 3(2012), pp. 185-190.

[11] Maneski, T.; Milošević-Mitic, V. Numerical and experimental diagnostics of structural strength. // Structural Integrity and Life. 10, 1(2010), pp. 3-10.

[12] Maksimović, S.; Ilić, I. Strength analysis of mechanically fastened joints on composite plates. // Structural Integrity and Life. 8, 1(2008), pp. 23-30.

[13] Živković, I.; Maksimović, S.; Aleksić, R. Numerical and Experimental Analysis of Initial Failure of Composite Laminates with Embedded Fiberoptic Sensors. // Structural Integrity and Life. 4, 3(2004), pp. 137-148.

[14] Ćirković, B.; Čamagić, I.; Vasić, N.; Ilić, A. Research on the Influence of Composite Materials on the Integrity of the Supporting Structure of the Machine Exposed to Variable Stress. // Structural Integrity and Life. 13, 2(2013), pp. 125130.

[15] Mikoč, M.; Bjelobrk, I.; Korajac, J. Alkali-activated fly ash concrete (Concrete without cement). // Tehnički vjesnikTechnical Gazette. 18, 1(2011), pp. 99-102.

[16] Popović, P. Machines for Forming, I and II part (in Serbian), University of Niš, 1995.

\section{Authors' addresses}

\author{
dr Bogdan Cirković, professor \\ dr Ivica Čamagić, assistant professor \\ Nemanja Vasić, assistant \\ Faculty of Technical Sciences, \\ 7 Kneza Miloša Street, \\ Kosovska Mitrovica Serbia \\ Phone: +38128425320 \\ Fax: +38128425322 \\ E-mail: bogdan.cirkovic@pr.ac.rs \\ E-mail: ivica.camagic@pr.ac.rs \\ E-mail: nemanja.vasic@pr.ac.rs
}

Zijah Burzić, scientific advisor

Military Institute of Techniques

1 Ratka Resanovića Street

Belgrade, Serbia

Phone: +381 112508308

Fax: +381 112508474

E-mail: zijah_burzic@rvkds.net

Boris Folić, researcher

University of Belgrade

Innovation Center of the Faculty of Mechanical Engineering

16 Kraljice Marije Street

Belgrade, Serbia 